medical training. In this respect, the West has something to learn from Thailand.

We thank Sanjai Sangvichien, Bangkok, for background information; Wiphawi Hipkaeo, Phitsanulok, for support and many helpful comments; and the Thai teachers and students who received us with such great friendliness. We also thank Ronald Frankenberg for supervision of AW's fieldwork and Kimberly Rosegger for help with the manuscript.

Contributors and sources: Both authors have a German medical background and currently teach anatomy to medical students. This paper arose from AW's MSc dissertation in medical anthropology (Brunel University), during which he conducted two months of anthropological fieldwork (participant observation in the dissecting room and informal interviews with faculty members and students) in Phitsanulok. FHG spent over three years working as an anatomist in Thailand. AW is the guarantor. Competing interests: None declared.

1 Furness P. Consent to using human tissue. BMJ 2003;327:759-60.

2 Hafferty FW. Cadaver stories and the emotional socialization of medical students. J Health Soc Behav 1988;29:344-56.

3 Tuffs A. Von Hagens faces investigation over use of bodies without conTuffs A. Von Hagens faces
sent. BMJ 2003;327:1068.

4 Shaffer K. Becoming a physician: teaching anatomy in the digital world. N Engl J Med 2004;351:1279-81.

5 McLachlan JC, Bligh J, Bradley P, Searle J. Teaching anatomy without cadavers. Med Educ 2004;38:418-24.
6 Popp RL. American missionairies and the introduction of western science and medicine in Thailand 1830-1900. Missiology 1985;13:147-57. Suwanwela C. International co-operation and practice: a view from Thailand. Med Educ 1996;30: 401-4.

land. Med Educ 1996;30: 401-4.
Ongcharit C, Ongcharit P. Intrathoracic organ transplantation in Thailand. Transplant Proc 1998;30:3385-6.

9 Schotzinger KA, Kirkley Best E. Closure and the cadaver experience: a memorial service for deeded bodies. Omega J Death Dying 1987;18:21727.

10 Dyer GS, Thorndike ME. Quidne mortui vivos docent? The evolving purpose of human dissection in medical education. Acad Med 2000;75:969-

11 Hull SF, Shea SL. A student-planned memorial service. Acad Med 1998;73:577-8.

12 Bertman SL, Marks SC. Humanities in medical education: rationale and resources for the dissection laboratory. Med Educ 1985;19:374-81.

13 Olson GA. Thai cremation volumes: a brief history of a unique genre. Asian Folklore Studies 1992;51:279-94.

14 Sukol RB. Building on a tradition of ethical consideration of the dead. Hum Pathol 1995;26:700-5.

15 Segal DA. A patient so dead: American medical students and their cadavers. Anthropol Q 1988;61:17-25.

16 Lella JW, Pawluch D. Medical students and the cadaver in social and cultural context. In: Lock M, Gordon DR, eds. Biomedicine examined. Dordrecht: Kluwer, 1988:125-53.

17 Good BJ. Medicine, rationalitiv, and experience: an anthropological perspective. Cambridge: Cambridge University Press, 1994

18 Hafferty FW. Into the valley: death and the socialization of medical students. Hafferty FW. Into the valley: death and the
New Haven: Yale University Press, 1991.

19 Rosenfield PJ, Jones L. Striking a balance: training medical students to provide empathetic care. Med Educ 2004;38:927-33.

(Accepted 7 September 2004)

\title{
The relentless therapeutic imperative
}

\section{Charlotte Paul}

Decisions about care near the end of life are always difficult, even more so when a relative has a progressive neurological illness

\section{Sweet rose, whose hue angry and brave \\ Bids the rash gazer wipe his eye, \\ Thy root is ever in its grave, \\ And thou must die.}

\section{From Virtue by George Herbert}

This is a story about the experience of making decisions about when to choose interventions near the end of life. It is about the difficulty of making those decisions for a close relative. It is not a story about good and bad doctors, though their recognition of the difficulties can make a difference. And it is about a special difficulty faced by people with a long term progressive neurological illness and their close relatives. As relatives, we have been caring for people with illnesses whose potentially lethal complications can be managed medically so that the person stays alive with ever increasing disability. We fear that dying will be drawn out interminably, past our capacity to care. Ideas of autonomous decision making by the ill person are not sufficiently helpful-nor is there just one choice to make about whether to accept interventions, but many decisions, each one closely related to particular circumstances. We would be helped by doctors and nurses who were prepared to advise when further treatment might be too burdensome.

\section{Why did I feel so appalled?}

When the consultant recommended the PEG (percutaneous endoscopic gastrostomy) I was appalled, and in my shock wanted to tell him that he could have my husband too, if he liked, as his husband, well maybe as his brother. Speaking from among his circle of junior doctors and nurses around my husband's bed, the consultant had responded to my observation that, as well as the new infection, my husband had been getting very thin. He said, "There is an operation, to put a tube directly into your stomach to feed you. It is quite safe. You will put on weight and feel better. Do you want it?" My husband nodded. "Good, we'll get it organised." Perhaps we should talk more about it, I ventured. I took aside the registrar, whom I knew: "Can I talk to you?" " If you like," she said; "don't let yourself be rushed into anything."

I went back to work in tears, angry and dismayed, and told my friends and colleagues about the prospect of the stomach tube. Why did I feel so appalled? Why did I feel it in my guts? It was partly the further assault on his frail body, partly the bags of ugly stuff I'd seen in the ward kitchen-like predigested food in a blood bag. Partly it was the memory of another younger man I'd once seen lying in a bed beside my husband's, unable to move or speak, visited occasionally by a nurse to put stuff into his stomach, but by no one else. And partly it was the shape of life. How long can anyone drag out an illness? And on top of the neurological damage of multiple sclerosis there were the infections-of bladder and bowel and lungs in rotation-each one requiring an emergency admission, first (for many years) from home, then in the last three years, from the local geriatric hospital. There were now two days in the week that I generally didn't see him. Sunday was always his
Department of Preventive and Social Medicine, University of Otago Medical School, Dunedin, New Zealand

Charlotte Paul associate professor of epidemiology

charlotte.paul@ stonebow.otago.ac.nz

BMJ 2004;329:1457-9 


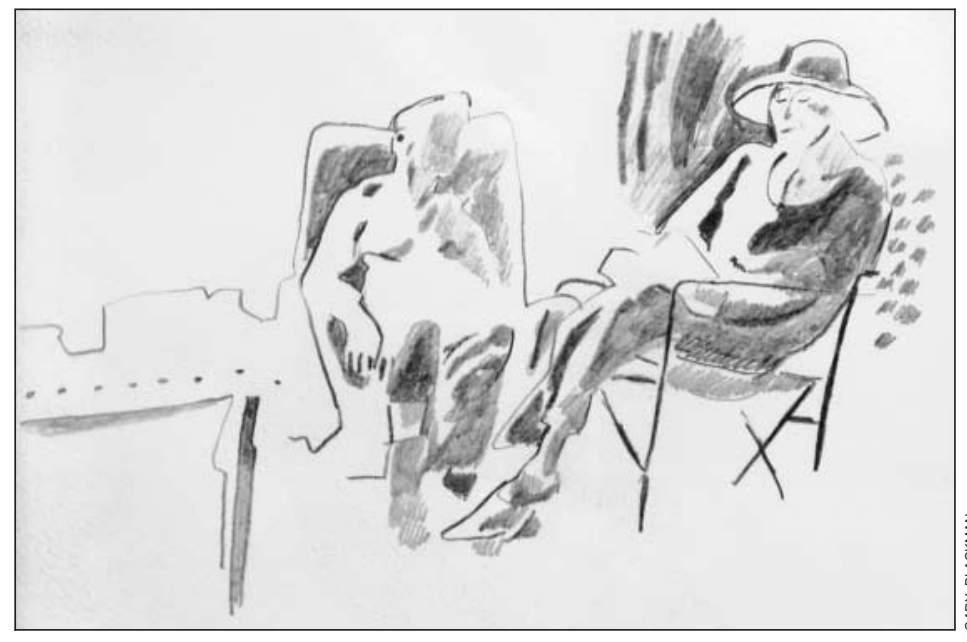

Reading by Joanna Margaret Paul, 1997

day at home. And there were still up to a dozen regular visitors and readers plus our son and his girlfriend.

\section{The shape of life}

The shape of life is the hard one. Fifteen years ago it had been hard for him to see the future shape and hard to handle the present: how many times did he stumble out to the lavatory at night and stand shaking and holding on while urine splashed everywhere. "I hate life!" he would yell in the dark. Later, when walking was no longer possible he would threaten to throw himself out of the bed. "But it would be no use, I wouldn't manage to kill myself." Later, he withheld his anger from me, and we were both freer. Maybe the loss of short term memory helped, and the antidepressants. In the last seven years at home there were regular fortnights in hospital: periodic detention, we called it. Though only in his 50s, he was now in a geriatric hospital. It was the only place where he could have a single room and be relatively close at hand.

To begin with he asked me every day why he was in hospital and please could he go home. I explained that I was worn out. After he had been in the public hospital twice with septicaemia the following Christmas, he asked about it: would it happen again? Yes, it might, I said, but you can have antibiotics again. I don't want them next time, he said. I told the general practitioner, but I think everyone except me forgot by next time.

Now the shape of life seems harder for me to handle than for him. We all go on reading to him. I read his well known and loved poets: Hardy, Wordsworth, Frost, Yeats, Herbert, Eliot, Larkin, Glover, and Baxter. He can't move at all. He is bored, lonely, and helpless, and his speech is hard to understand. But he lights up with pleasure at people and words and told a nurse doing a project on life histories that his children were what kept him going. After the Christmas septicaemia, I had nearly a year of painful depression before I could find a way to go forward again. Now I am a witness. Of course I provide practical help, I endlessly chide and encourage the nurses and occupational therapists to attend to his changing needs. The last six months the main need has been how to get enough food and thickened fluid into him. Yet I can't stop him suffering.

\section{Admissions}

The serious infections started when he had a urinary catheter put in nine years ago. He developed septicaemia and a scrotal abscess. Since then death has seemed close by. I have lost count of the number of hospital admissions for infection. I sit and stand beside him in the emergency department, not sure if he is conscious enough to recognise the lines of poetry I read to sustain us both. This last time I had a little book of the metaphysical poets. The poems all seem to be about death one way or another. It isn't chance that we both choose these poems. In George Herbert's meditations there is a shape to life and death. Even Andrew Marvell's To His Coy Mistress has “Time's winged chariot hurrying near/And yonder all before us lie/Deserts of vast eternity." In the emergency department we seem to be known and always treated gently.

After the previous admission I had met with the consultant and we had discussed future admissions. The consultant explained that if it was aspiration pneumonia again, antibiotics might make little difference. If his fluid intake could be sustained with subcutaneous fluids and the nurses could cope, he could stay out of the public hospital, which he found noisy and confusing and hated. But it was not clear what the next fever was-possibly a urinary infection, possibly pneumonia. He was quickly dehydrated and consciousness was diminished. The after-hours doctor recommended an ambulance. The emergency department doctors gave him intravenous fluids and intravenous antibiotics.

\section{Considerations}

It was the following morning in the ward that the consultant recommended the gastrostomy tube. After my day of anger and confusion the registrar phoned and we met to talk about antibiotics. The Pseudomonas grown from the urine was resistant to almost everything; his temperature had gone up again last night; the antibiotic needed changing. What did I think about using tobramycin? She talked about the pros and cons of different options and appropriately made her decision. We also discussed the gastrostomy. She thought the consultant and I had misunderstood each other. He thought that if my husband was having any treatment (the antibiotics) then we wanted every treatment. It was more black and white for him, she said. She had discussed with him how even the situation of giving up antibiotics when someone has septicaemia is different from not using antibiotics when someone is only moderately ill. I explained that we couldn't just refuse antibiotics on our own. We were dependent on the nurses and doctors and needed their support through the final illness. We left the decision about the gastrostomy alone while my husband was still febrile and talked about how to get sustaining food into him to prevent hunger.

The next time I saw the registrar my husband's fever had settled. She had organised thickened protein-rich milkshakes and had shown the nurses how to feed him, small amounts at a time, with little choking. She had listened to him and answered what she could make out of his questions. She had thought of two reasons against the operation: that the nurses 
could be less likely to spend time with him, feeding him, and that if it prolonged life, it would be for more grave infections to be repeated. We discussed that, with his memory loss, it was easier for him than for me not to look forward and back. I spoke to our daughter, who was a first year house surgeon in the North Island. She talked about her experiences of PEG tubes-about a man with cancer of the oesophagus who had had terrible excoriation around his gastrostomy site, and about a woman who had had the procedure after a stroke, a decision our daughter had felt morally uncertain about.

My husband and I have had further talks about this. Well, I talked and deciphered his responses. In the last he said he didn't want it. He said he was not frightened by the prospect of his death. Our son and I talked to the registrar again, the day of his discharge. "What shall we do the next time he gets an infection? The after-hours doctor won't know him and will want to admit him to hospital. I won't want to take a different position unsupported, and the nurses will be helpful but unsure of their ability to cope. Then, when he goes to hospital, that will be seen as an indication for treatment." Yes, she said, he should be admitted if the diagnosis is uncertain, but not necessarily for treatment. There, with better diagnostic facilities, it will be clearer what we are dealing with. Depending on the diagnosis, he can be treated with antibiotics or cared for in a side room in the hospital with experienced staff and us.
This very experienced registrar had first met my husband when she was a medical student. Now she had, over several conversations, helped to give a shape to the future which all of us could make some sense of. The therapeutic imperative, exercised by many different doctors, each focusing on the patient in front of them, provides a kind of certainty to which patients and relatives can submit. But sometimes it becomes a monster and pushes patient and relatives beyond endurance.

\section{Epilogue}

After this account was written, my husband put on some weight, helped by our extra efforts to feed him. Nine months later he died. He became unable to swallow almost entirely in the couple of weeks before he died. He was kept hydrated with subcutaneous fluids. His oft repeated "How long have I got?" could be tentatively answered. He was aware of his last days and hours and all his family was with him. In the end it was not necessary for him to go to the public hospital. The nurses at the geriatric hospital kindly shared his care with the family.

I thank Ruth and Tom Cunningham for comments on the draft manuscript.

Competing interests: None declared.

\section{Mind over matter?}

Lucy and Dan (not their real names) were expecting their first baby in 1992, when Lucy was 26 . Hypertension resulting from pregnancy meant that labour had to be induced at 37 weeks' gestation, and a girl of $2.8 \mathrm{~kg}$ was born by normal delivery. Twelve months later Lucy had another girl of the same weight by normal delivery. Twenty months later a boy saw first light. He weighed a bit more but still came normally. Nearly three years later Lucy was pregnant again. This time the hypertension returned and, with it, intrauterine growth restriction. At 35 weeks' gestation the Doppler studies weren't reassuring. A boy weighing $2.3 \mathrm{~kg}$ was delivered by caesarean section.

Over the next year Lucy had two first trimester miscarriages. Then at 31 weeks into her seventh pregnancy (already complicated by placenta praevia) her membranes ruptured and premature labour ensued. Her fifth child was delivered by emergency caesarean section-the smallest baby, a girl of $1.9 \mathrm{~kg}$. She did well. Next was Lucy's millennium baby: in June 2000 at 36 weeks a girl was delivered by caesarean section, as blood pressure problems had recurred.

One year later, with Lucy again pregnant, she and Dan decided that this, the ninth pregnancy, would be the last. In June 2001 she was delivered of a $3.1 \mathrm{~kg}$ healthy boy, her seventh child and fourth caesarean. Both uterine tubes were doubly tied and the mid-section excised (by the Pomeroy technique) and sent to pathology for confirmation.

So with seven healthy children, from the newborn son to the eldest girl of nine, Dan and Lucy settled to bringing up their large family and making a living.

But-then came the surprise. Less than two years later, Lucy, now 37 , started to feel broody. Specious perhaps, but she wanted another child. The urge was strong; she was thinking of making inquiries about reversing the sterilisation when she realised that her period hadn't arrived. Sure enough, the line showed up in the

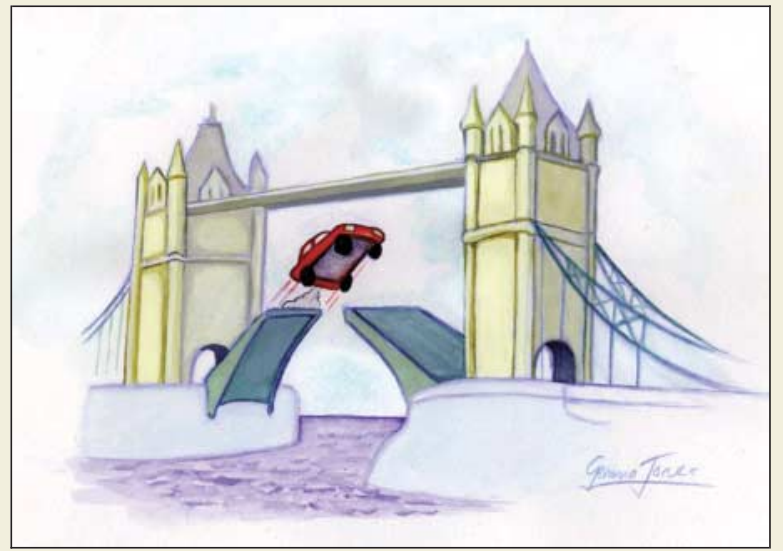

middle window of the test stick, and a scan showed a viable intrauterine pregnancy. Lucy was delighted. After the baby boy was safely delivered by caesarean section, we took a close look at the remnants of the tubes. They hadn't re-anastomosed, and the proximal and distal severed ends were free on both sides. This time we took out both tubes in their entirety, and the pathologist once again confirmed the clinical appearance.

Did willpower help the oocyte to jump the gap? Isn't it wonderful how nature can work miracles-and that, when surprises occur, not everyone wants to blame somebody?

Alastair C McKelvey (alastairmckelvey@doctors.org.uk) specialist registrar, obstetrics and gynaecology,

James C Dornan consultant obstetrician and gynaecologist, Royal Jubilee Maternity Service, Belfast 